\title{
Early Holocene wetland succession at Lake Flixton (UK) and its implications for Mesolithic settlement
}

\author{
Barry Taylor $^{1}$ (D)
}

Received: 29 May 2018 / Accepted: 23 January 2019 / Published online: 28 February 2019

(c) The Author(s) 2019

\begin{abstract}
This paper reports on new research into the timing and nature of post-glacial environmental change at Lake Flixton (North Yorkshire, UK). Previous investigations indicate a succession of wetland environments during the early Holocene, ultimately infilling the basin by ca 7,000 cal BP. The expansion of wetland environments, along with early Holocene woodland development, has been linked to changes in the human occupation of this landscape during the Mesolithic (ca 11,300-6,000 cal вР). However, our understanding of the timing and nature of environmental change within the palaeolake is poor, making it difficult to correlate to known patterns of Mesolithic activity. This paper provides a new record for both the chronology and character of environmental change within Lake Flixton, and discusses the implications for the Mesolithic occupation of the surrounding landscape.
\end{abstract}

Keywords Mesolithic $\cdot$ Early Holocene $\cdot$ Plant macrofossils $\cdot$ Environmental change $\cdot$ Lake Flixton $\cdot$ Star Carr

\section{Introduction}

Since the late 1940s evidence for intensive phases of early prehistoric activity has been recorded around Lake Flixton in the eastern Vale of Pickering (North Yorkshire, UK) (Fig. 1a, b). The lake formed at the start of the Late-glacial interstadial (ca 14,600 ka cal вP) and gradually in-filled with calcareous and organic sediments that preserved a rich record of both the human and environmental history of the landscape (e.g. Clark 1954; Walker and Godwin 1954; Mellars and Dark 1998; Conneller and Schadla-Hall 2003; Taylor 2011; Milner et al. 2018). The area is best known for the early Mesolithic site of Star Carr where a large assemblage of bone and antler artefacts, faunal remains and worked flint were recovered from sediments at the former lake edge (Clark 1954). However, a further 20 sites, dating

Communicated by M. O’Connell.

Electronic supplementary material The online version of this article (https://doi.org/10.1007/s00334-019-00714-9) contains supplementary material, which is available to authorized users.

Barry Taylor

b.taylor@chester.ac.uk

1 Department of History and Archaeology, University of Chester, Parkgate Road, Chester CH1 4BJ, UK to the final Palaeolithic, terminal Palaeolithic and the early and late Mesolithic have also been recorded (Fig. 2) (Conneller and Schadla-Hall 2003). Early Mesolithic activity (ca 11,300-9,500 cal вP) was particularly intensive. Recent work at Star Carr has shown that the site was occupied for ca 800 years, with evidence for the construction of large timber platforms, post-built structures, and the deliberate management of lake-edge vegetation (Dark 1998a; Conneller et al. 2012; Milner et al. 2018). Other sites also show evidence for multiple phases of occupation, in some cases spanning centuries (Conneller and Schadla-Hall 2003; Taylor 2018), as well as evidence for post-built structures (Taylor and Gray Jones 2009) and controlled burning of the wetland vegetation (Cummins 2003). Together this suggests a long-term commitment to particular places in this landscape that stands in contrast to established views of the period (Conneller et al. 2012; Milner et al. 2018). Late Mesolithic occupation (ca 9,500-6,000 cal BP) is also known from multiple locations, in some cases continuing from the earlier part of the period. Whilst these sites have been less extensively studied there is evidence for comparably intensive forms of activity including the use of structures (Taylor 2012) and management of both wetland and terrestrial vegetation through burning (Cummins 2003).

It has been argued that the scale of early Mesolithic activity was due to the rich and productive wetland environments 
Fig. 1 Maps showing the location of the study area; $\mathbf{a}$ the study area in relation to northwest Europe, b Lake Flixton in relation to the present-day North Sea coastline and the coastal towns of Scarborough and Filey
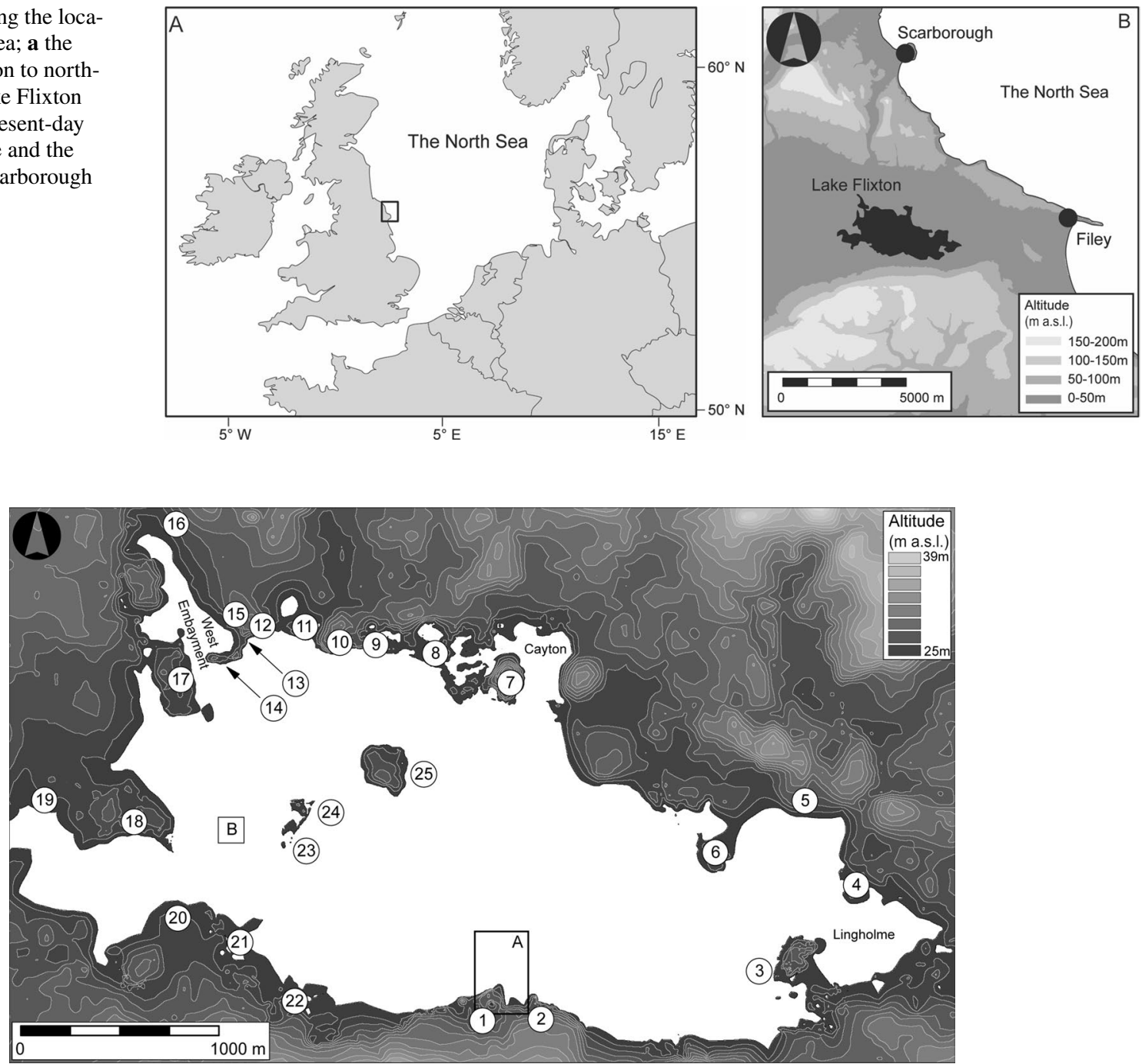

Fig. 2 Map of Lake Flixton showing the approximate extent of the lake at the start of the Mesolithic, based on an estimated lake level of $24 \mathrm{~m}$ a.s.l. (see Taylor and Alison 2018), and taking into account the local topography. a Survey area at Flixton School House; b position of Dark's (1998b) deep lake profile. Known areas of Mesolithic activity are marked as follows: 1: Flixton School House Farm. 2: Flixton School Field. 3: Barry's Island. 4: Lingholme Farm Site A. 5: Kill-

forming within the lake, and that the subsequent in-filling of the basin, coupled with changes to the terrestrial woodland, led to the abandonment of sites and an overall decline in activity (Mellars 1998, pp 229-231). However, our ability to determine the significance of environmental change is hampered by a poor understanding of the timing and nature of wetland succession. The principal issue is chronology. There are only two reliably dated records for the spatial and temporal development of the wetlands, both of which relate to the lake-edge environments in the early Mesolithic. The most detailed comes from Star Carr where Dark (1998a) documented the development of the marginal vegetation by recording pollen and plant macrofossil profiles at intervals erby Carr. 6: Lingholme Farm Site C. 7-9: Cayton Carr. 10: Manham Hill. 11: Seamer C. 12: Seamer B and Rabbit Hill. 13: Seamer Carr K. 14: Seamer D. 15: Seamer Carr L and N. 16: Seamer Carr F. 17: Ling Lane. 18: Star Carr. 19: Flixton 9. 20: VP site D. 21: VP site E. 22: Woodhouse Farm. 23: Flixton Island site (1) 24: Flixton Island site (2) 25: No Name Hill

from the shore. However this record does not continue later than ca 10,000 cal BP and only extends ca $10 \mathrm{~m}$ into the lake. A more spatially extensive record was established by the author at Flixton School House Farm (henceforth Flixton SHF), where plant macrofossil analysis was carried out on samples from two cores, one at the former lake edge and the other $50 \mathrm{~m}$ into the basin (Taylor 2011). Again, however, this provides no information on the timing and character of wetland succession in the deeper parts of the lake during the late Mesolithic. Of the remaining dated records, most consist of individual pollen or plant-macrofossil profiles from sediments in the relatively shallow lake margins close to the shore (Cummins 2003; Taylor 2011), with only two 
profiles documenting the later expansion of wetlands into the deepest parts of the basin (Day 1996; Dark 1998b; Cummins 2003). As a result, there is little indication of the rate at which wetland succession occurred or the varying extents of the different environments other than at the very edge of the lake in the early Mesolithic.

The sequence of wetland succession and the effects of changes in the lake's hydrology are also debated. Cloutman (1988b, p 31) argued that the hydrosere was reversed during the late Mesolithic by a rise in lake level that caused areas of Carr to be replaced by reedswamp. He also suggested that rising lake levels caused organic deposits to form over areas of previously dry ground above the lakeshore (Cloutman 1988a, p 14). However, Cummins (2003, pp 320-321) has argued that, whilst there were short-lived fluctuations in lake level, the hydrosere developed in a broadly linear manner with no evidence for a sustained rise in lake level.

These issues make it difficult to establish the potential effects that environmental change had upon the character of Mesolithic settlement. To resolve this a new programme of plant macrofossil analysis and radiocarbon dating was undertaken to establish a more detailed account of the spatial and temporal development of the lake environments. By bringing the results of this study together with previous palaeo-environmental and archaeological research in the area, it is now possible to describe the evolution of the wetland and terrestrial environments during the Mesolithic, and to discuss the implications for the human occupation of this landscape.

\section{Materials and methods}

Fieldwork was undertaken between 2008 and 2012 at Flixton SHF (Figs. 2, 3a, b) in conjunction with archaeological investigations of an early and late Mesolithic settlement (Taylor and Gray Jones 2009). Three trenches (F, H and I) were excavated to sample the deposits at the former lake edge (trench F) and the adjacent higher ground (trenches $\mathrm{H}$ and I), and an auger transect was recorded between them to produce a complete stratigraphic profile. Three cores (A-C) were taken to sample the deposits within the lake basin (Fig. 3a, b). The early Mesolithic sequences at trench F and core A have previously been reported (Taylor 2011).

\section{Plant macrofossils}

A contiguous sequence of samples, 35-50 mm thick, was cut from the east-facing section of trench F, bulk samples (11) were taken from stratigraphic units in trenches $\mathrm{H}$ and $\mathrm{I}$, and cores $\mathrm{A}-\mathrm{C}$ were taken using a Russian auger, carried off-site, and divided into $35-50 \mathrm{~mm}$ thick samples. These were sub-sampled (sample volumes: $50 \mathrm{~cm}^{3}$ from

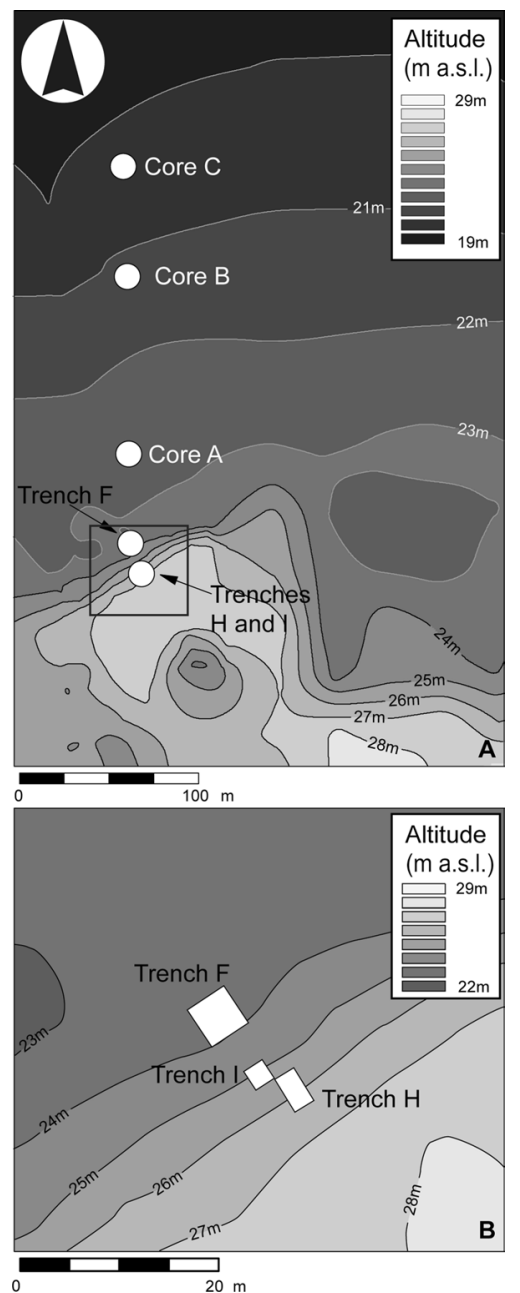

Fig. 3 a Coring and trench locations at Flixton School House Farm in relation to basal topography, and $\mathbf{b}$ detailed map showing location of the trenches. The location of the survey area in relation to the lake is shown in Fig. 2

the cores, $100 \mathrm{~cm}^{3}$ from trench $\mathrm{F}$, and $1,000 \mathrm{~cm}^{3}$ from $\mathrm{H}$ and I), disaggregated in $8 \%$ sodium hydroxide, and washed through nested sieves ( $2 \mathrm{~mm}-125 \mu \mathrm{m}$ mesh). Each sieve fraction down to $125 \mu \mathrm{m}$ was analysed using a Zeiss Stemi DV4 stereo microscope and, where necessary, a Zeiss light microscope $(400 \times$ and $1,000 \times$ magnification $)$. All macrofossils that could be identified to a specific taxon were counted, with the exception of fragments of Nymphaea alba seed and fern sporangia which were recorded in terms of abundance. The results were plotted quantitatively as the number of macrofossils of each taxon/species per sample using program C2 version 1.6.6 (Juggins 2010), with the exception of trenches $\mathrm{H}$ and I where the material was too sparse. Identifications were carried out using Cappers et al. (2006), Grosse-Brauckmann (1972, 1974, 1992), and a modern reference collection. Higher plant nomenclature follows Stace (2010). 


\section{Wood taxonomic identifications}

Fifty-one samples were taken from nine layers of wood in the lower part of trench F (23.47-24.18 m a.s.1.). A further 10 samples were taken from a homogenous layer of wood toward the top of the trench (25.52-25.66 m a.s.1.) but were too poorly preserved for taxonomic identification. Wood from the intervening deposits consisted entirely of intrusive root and was not analysed. Samples were taken during the excavation, and the levels recorded using a Leica T300 total station. Thin sections of wood samples were removed from the radial, transverse and transversal planes, mounted on slides, examined under $10 \times$ to $30 \times$ magnification and identified using Schweingruber (1990).

\section{Radiocarbon dating}

Nineteen radiocarbon dates were obtained on samples from trench $\mathrm{F}$ and cores $\mathrm{A}-\mathrm{C}$ to establish a chronology for the environmental profiles (Table 1 and ESM Table 1). Samples were taken from monolith tins/cores, and from bulk macrofossil samples. Dating was undertaken by the Oxford Radiocarbon Accelerator Facility with the exception of sample FSH-A-1, which was dated by Beta Analytic. Radiocarbon dates were calibrated using OxCal 4.2

Table 1 Radiocarbon ages, and calibrated and modelled dates from trench $\mathrm{F}$ and cores A-C

\begin{tabular}{|c|c|c|c|c|c|c|}
\hline Sample code & Environmental zone/event & Age (year вр) & Calibrated age (cal вр) & Probability & Modelled age (cal вр) & Probability \\
\hline \multicolumn{7}{|c|}{$P$ Sequence trench $F$} \\
\hline & End of profile $F$ & & & & $6,970-6,440$ & 95.4 \\
\hline OxA-22208 & & $6,085 \pm 30$ & $7,160-6,800$ & 95.4 & $6,980-6,850$ & 95.4 \\
\hline \multirow[t]{2}{*}{ OxA-22207 } & & $6,040 \pm 30$ & $6,970-6,790$ & 95.4 & $7,000-6,860$ & 95.4 \\
\hline & Start zone F5 & & & & $7,420-7,090$ & 95.4 \\
\hline OxA-22063 & & $6,365 \pm 38$ & $7,420-7,170$ & 95.4 & $7,430-7,250$ & 95.4 \\
\hline \multirow[t]{2}{*}{ OxA-22206 } & & $6,551 \pm 33$ & $7,560-7,420$ & 95.4 & $7,560-7,420$ & 95.4 \\
\hline & Start zone F4b & & & & $8,620-7,450$ & 95.4 \\
\hline OxA-22179 & & $8,175 \pm 37$ & $9,260-9,010$ & 95.4 & $9,250-9,, 010$ & 95.4 \\
\hline OxA-22178 & & $8,286 \pm 37$ & $9,430-9,130$ & 95.4 & $9,440-9,150$ & 95.4 \\
\hline OxA-22177 & & $8,569 \pm 37$ & $9,600-9,480$ & 95.4 & $9,590-9,480$ & 95.4 \\
\hline OxA-22176 & Start zone F4a & $8,885 \pm 38$ & $10,190-9,790$ & 95.4 & $10,110-9,770$ & 95.4 \\
\hline OxA-22175 & & $8,842 \pm 38$ & $10,160-9,730$ & 95.4 & $10,170-9,890$ & 95.4 \\
\hline \multirow[t]{2}{*}{ OxA-22174 } & Start zone F3 & $9,275 \pm 38$ & $10,580-10,290$ & 95.4 & $10,530-10,270$ & 95.4 \\
\hline & Start zone F2 & & & & $10,690-10,340$ & 95.4 \\
\hline OxA-22173 & & $9,475 \pm 40$ & $11,070-10,580$ & 95.3 & $10,870-10,580$ & 95.4 \\
\hline \multirow[t]{2}{*}{ OxA-23336 } & & $9,540 \pm 50$ & $11,100-10,690$ & 95.4 & $11,110-10,740$ & 95.4 \\
\hline & Start sedimentation at $\mathrm{F}$ & & & & $11,190-10,730$ & 95.4 \\
\hline \multicolumn{7}{|c|}{$P$ Sequence core $A$} \\
\hline \multirow[t]{4}{*}{ FSH-A-1 } & & $8,120 \pm 40$ & $9,250-8,990$ & 95.5 & $9,240-8,980$ & 95.5 \\
\hline & Start zone A4 & & & & $9,400-9,000$ & 95.4 \\
\hline & Lake level Rise & & & & $10,100-9,500$ & 95.4 \\
\hline & Start zone A3 & & & & $10,160-9,690$ & 95.4 \\
\hline OxA-22064 & & $8,795 \pm 55$ & $10,160-9,600$ & 95.4 & $10,180-9,740$ & 95.4 \\
\hline \multirow[t]{3}{*}{ OxA-22065 } & & $9,370 \pm 45$ & $10,720-10,440$ & 95.4 & $10,710-10,300$ & 95.4 \\
\hline & Start Zone A2 & & & & $11,120-10,360$ & 95.4 \\
\hline & Start sedimentation at A & & & & $11,690-10,460$ & 95.4 \\
\hline \multicolumn{7}{|c|}{ Sequence core B } \\
\hline OxA-33255 & Start zone B4a & $7,600 \pm 39$ & $8,510-8,340$ & 95.4 & $8,520-8,340$ & 95.3 \\
\hline OxA-33254 & Start zone B3 & $7,958 \pm 38$ & $8,990-8,640$ & 95.4 & $8,980-8,640$ & 95.4 \\
\hline \multicolumn{7}{|c|}{ Sequence core $C$} \\
\hline OxA-33257 & Start zone C4 & $6,887 \pm 37$ & $7,830-7,650$ & 95.4 & $7,830-7,660$ & 95.4 \\
\hline OxA-33256 & Start zone C3 & $7,168 \pm 37$ & $8,050-7,930$ & 95.4 & $8,040-7,880$ & 95.4 \\
\hline
\end{tabular}

Environmental zones/events refer to the plant macrofossil profiles recorded from trench F, and cores A-C. Information on the depths and dated material is in ESM Table 1 
(Bronk Ramsey 2009a, b) and the IntCal13 calibration curve (Reimer et al. 2013). Bayesian analysis has been undertaken using the functions in the OxCal software; deposition models $(P$-Sequence $)$ were produced for trench $\mathrm{F}$ and core $\mathrm{A}$, sequence models were produced for cores $\mathrm{B}$ and $\mathrm{C}$, and the Difference function was used to estimate the durations of key stratigraphic units and hiatuses in peat formation. Dates are expressed at two standard deviations (95.4\%) unless otherwise stated, and rounded to the nearest 10 years.

\section{Results}

\section{Stratigraphy}

Full sediment logs are available in supplementary files (ESM Table 2a, b). At the lake edge (trench F), the mineral substrate was overlain by a sequence of fine detrital mud, coarse reed peat and wood peat, sealed by a poorly sorted silty sand (ESM Table 2a). Above this was a coarse herbaceous detritus with two bands of much darker, denser humified peat. The herbaceous detritus and the uppermost layer of humified peat continued upslope into trench $\mathrm{H}$, with the humified deposit extending into trench I. Overlying these was a deposit of wood peat, extending across all three trenches, which in trench $\mathrm{F}$ graded into a mixed herbaceous/woody detritus. Sealing the sequence in all three trenches was a highly humified organic sediment grading into topsoil. The basin deposits were characterised by marl overlain by fine detrital mud (ESM Table 2b). In core A, this was succeeded by a sequence of reed peat, herbaceous detritus and wood peat, whereas in cores $\mathrm{B}$ and $\mathrm{C}$ a coarse, fibrous detritus overlay the fine detrital mud.

\section{Chronology}

In trench F organic sedimentation began at $11,190-10,730 \mathrm{cal}$ вP (Table 1). The deposition model shows a rapid and even rate of deposition up to $24.48 \mathrm{~m}$ a.s.1., becoming slightly slower and irregular above this (Fig. 4a). The duration over which the sand layer formed was modelled at 0-260 years. Hiatuses in peat formation were identified at the interface between each of the humified peat layers and the overlying sediment; the first (dated by OxA-22177 and OxA-22178) of between 70 and 350 years, the second (dated by OxA-22063 and OxA-22206) of between 10 and 230 years. The modelled age for the start of plant macrofossil zone F4b is poorly constrained but assuming an even rate of deposition in this part of the sequence it is likely that this transition occurred in the centuries around 8,000 cal вP.

In core A the onset of marl formation has been modelled at 11,690-10,460 cal вр (Table 1). The deposition model shows rates of sedimentation increasing from $22.86 \mathrm{~m}$, at the transition from fine to coarse detrital
Fig. 4 a Deposition model for trench $\mathrm{F}$ in relation to the stratigraphic sequence and the plant macrofossil zones, produced using OxCal v4.3.2 (Bronk Ramsey 2017) and the intCal13 calibration curve (Reimer et al. 2013). Probability distributions are shown at 95.4\%. b Deposition model for core A in relation to the stratigraphic sequence and the plant macrofossil zones produced using OxCal v4.3.2 (Bronk Ramsey 2017) and the intCal13 calibration curve (Reimer et al. 2013). Probability distributions are shown at 95.4\%
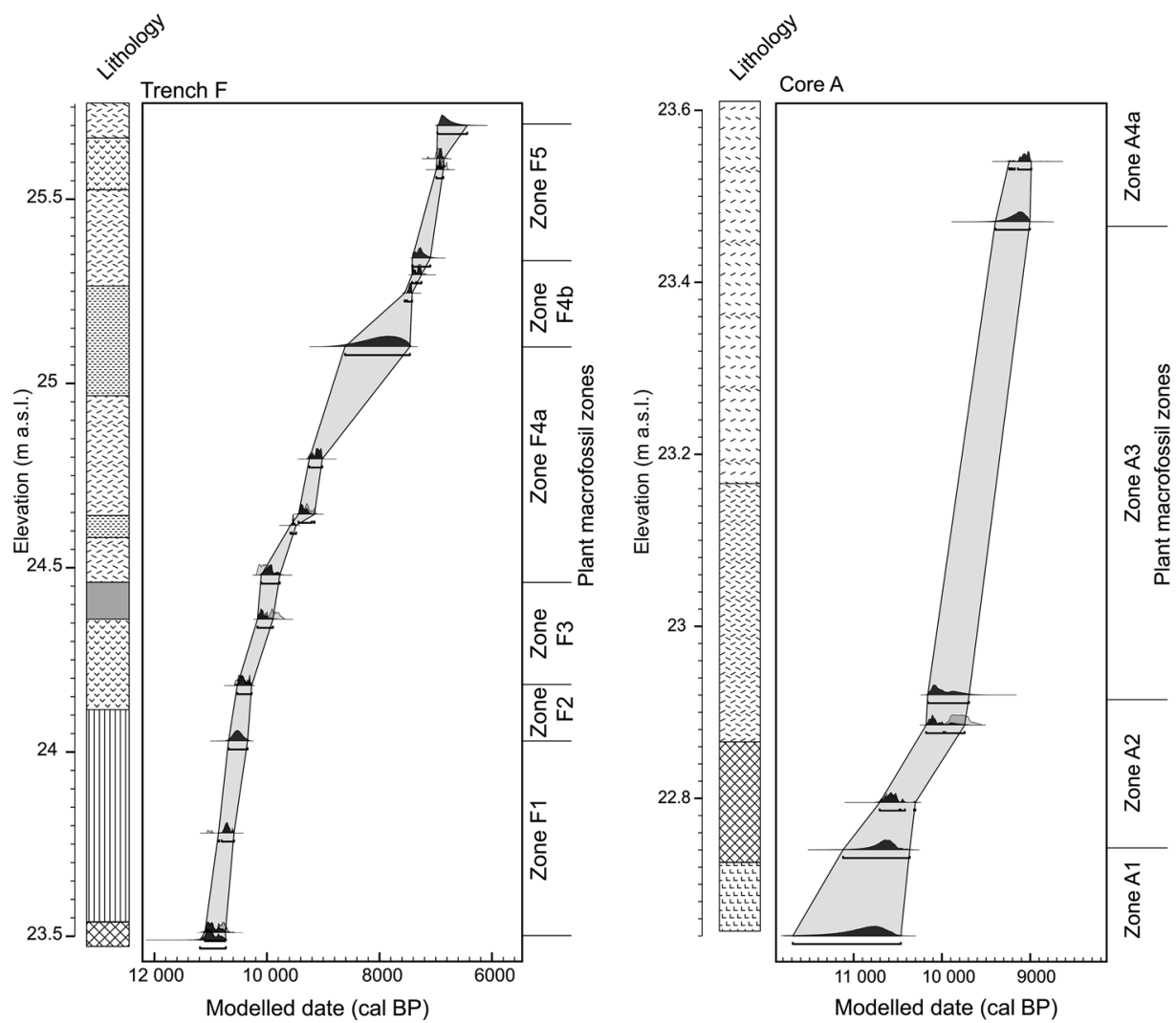
mud (Fig. 4b). Due to the lack of dates above $23.55 \mathrm{~m}$ no attempt has been made to model the top of the sedimentary sequence or the upper zones in plant macrofossil profile A.

There were insufficient dates to create reliable deposition models for cores B and C. Dates from core B established the age for the start of plant macrofossil zones B3 (OxA-33254) and B4a (OxA-33255), whilst those from core $\mathrm{C}$ dated the start of zone $\mathrm{C} 3$ (OxA-33256) and $\mathrm{C} 4$ (OxA-33257).

\section{Wood analysis}

Taxonomically identifiable material was recorded from the lower deposits of trench F (23.47-24.18 m) (ESM Table 3). Most of the wood consisted of stems or side branches of Salicaceae (Salix or Populus spp.) or Betula spp., with Viburnum spp. occurring at $24.07 \mathrm{~m}$, and Corylus avellana present from $24.07 \mathrm{~m}$ to $24.18 \mathrm{~m}$. A single stump of Salix/Populus was recorded at $24.18 \mathrm{~m}$. None of the material showed evidence of human modification, but sample 28F had been worked by beaver (ESM Table 3).

\section{Plant macrofossil analysis}

The results of the plant macrofossil analyses are presented in Figs. 5, 6 and 7 and Tables 2, 3, 4 and 5, with the exception of trenches $\mathrm{H}$ and I where the material was too sparse to be quantified. In Core $\mathrm{C}$ only the part of the sequence incorporating the decline and disappearance of aquatic material was investigated.

In trenches $\mathrm{H}$ and I, fragments of Eupatorium achenes occurred throughout the deposits, but in very low quantities, with Thalictrum achenes, and Betula fruits occurring occasionally. Alnus fruits were present in the upper deposits coinciding with the transition to wood peat.

\section{Discussion}

\section{Interpretation of the macrofossil and sedimentary sequences}

Trench F. Zone F1: 11,190-10,730 to 10,690-10,340 cal вр. Sedimentation began in standing water, with Phragmites, probably P. australis (Haslam 1972), growing at the site.

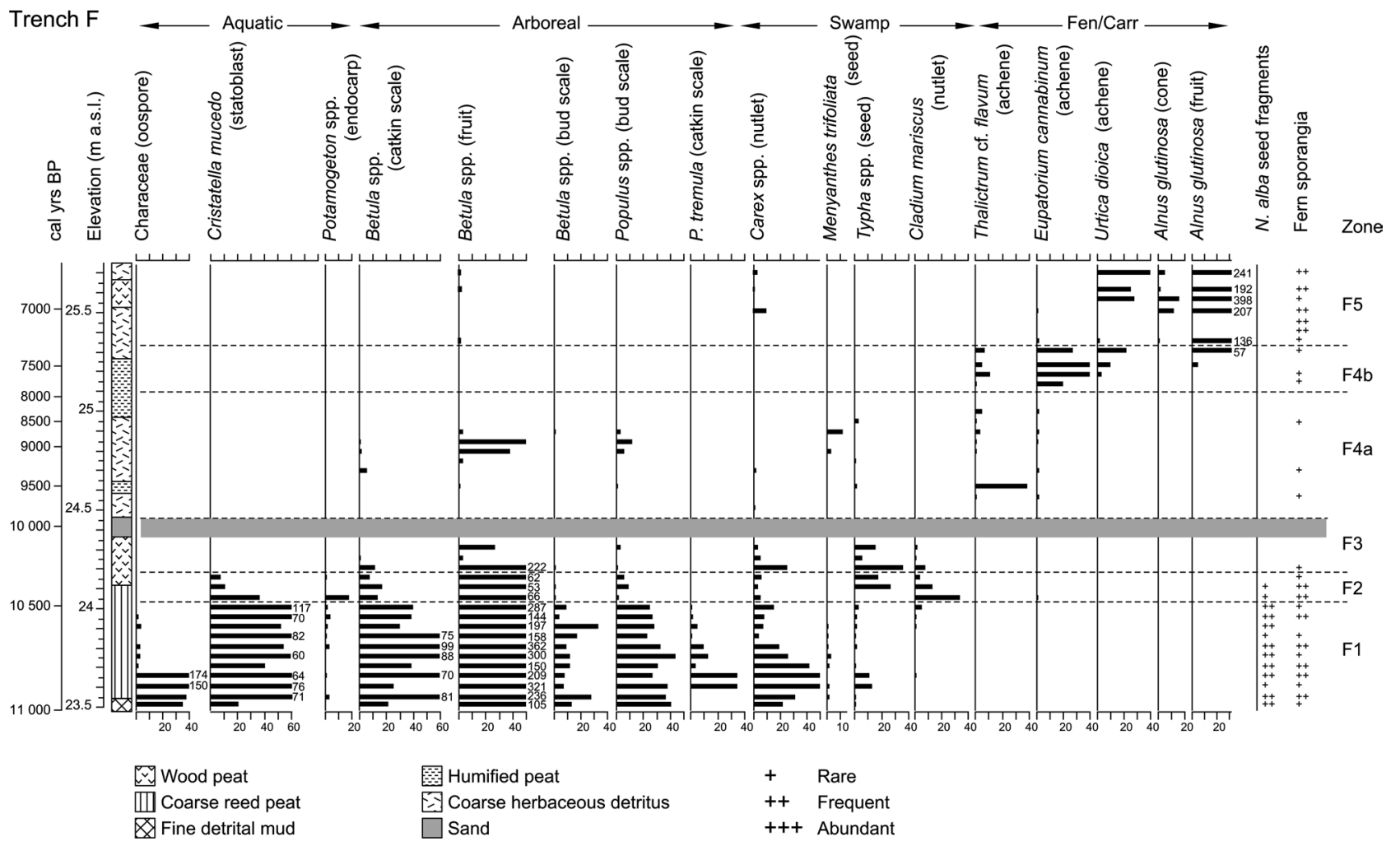

Fig. 5 Plant macrofossil profile and chronology, trench F (principal taxa). Total numbers of macrofossils of each taxon/species are presented, with the exception of Nymphaea alba seed fragments and fern sporangia which are expressed on an abundance scale. The profile has been divided into six zones based on changes in the plant macrofossil assemblages. The results are displayed stratigraphically, and biological taxa are grouped by broad habitat. The chronology is derived from the deposition model (see Fig. 4a) and is expressed as median ages. For rare taxa see Fig. S1 


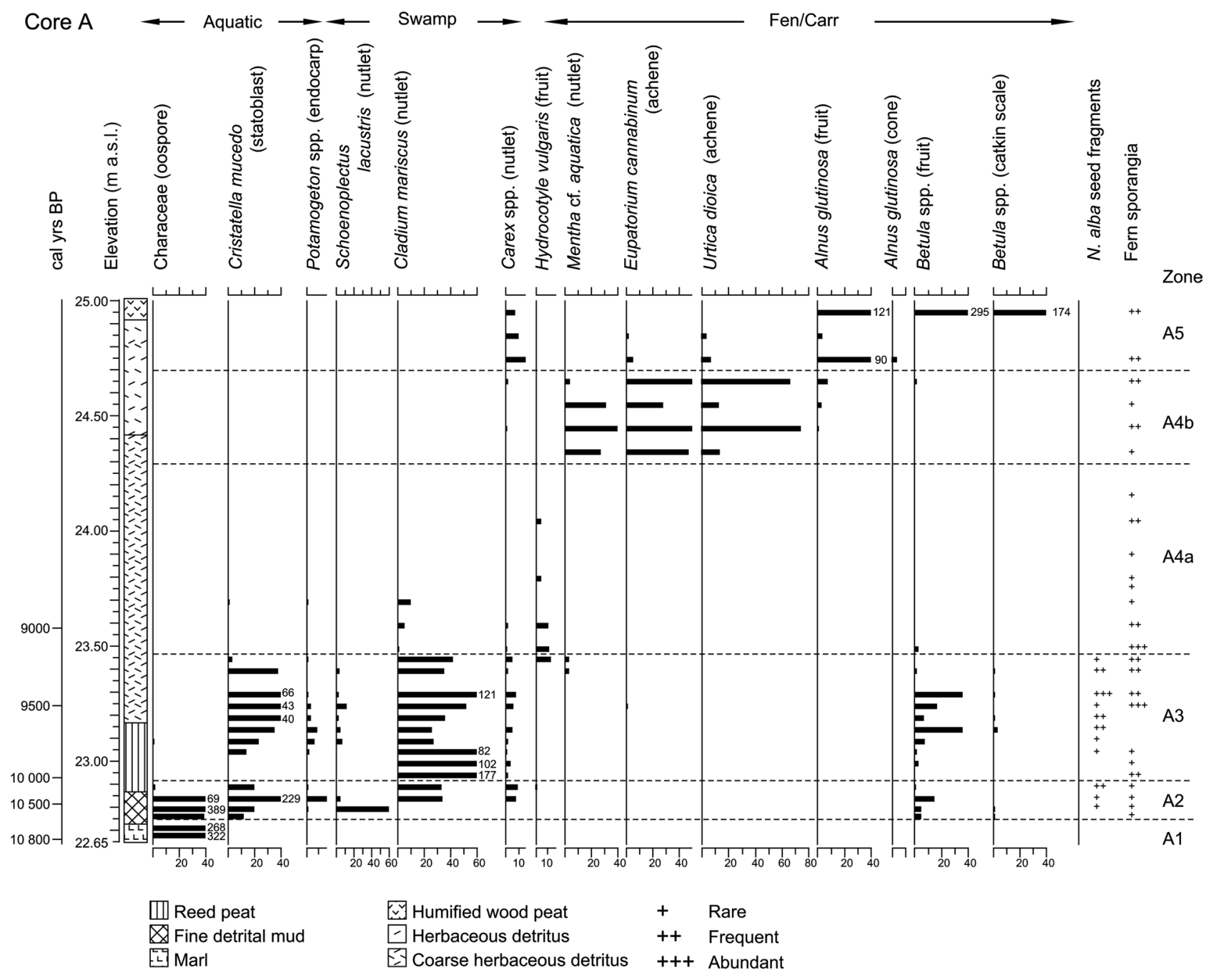

Fig. 6 Plant macrofossil profile and chronology, core A (all taxa). Total numbers of macrofossils of each taxon/species are presented, with the exception of Nymphaea alba seed fragments and fern sporangia which are expressed on a scale of abundance. The profile has been divided into six zones based on changes in the plant macrofossil assemblages. The results are displayed stratigraphically, and biological taxa are grouped by broad habitat. The chronology is derived from the deposition model (see Fig. 4b) and is expressed as median ages
A range of emergent and aquatic taxa were present in the wider area (notably Nymphaea, Potamogeton spp., Carex (including $C$. paniculata and C. rostrata), Menyanthes, and Typha spp.), though given the tendency of plant material to accumulate at lake edges these were not necessarily growing locally (e.g. Birks 1973; Zhao et al. 2006; Koff and Vandel 2008). The local growth of trees (B. pubescens, $B$. pendula, $P$. tremula, and possibly Salix spp.) at the shore is demonstrated by large Betula and Salix/Populus stems and branches within the sediments.

Zone F2: $10,690-10,340$ to $10,530-10,270$ cal BP. The decrease in the quantity and range of macrofossils reflects a reduction in the volume of water reaching the sediments (see also Dark 1998a, p 131), which is tentatively interpreted as a shift to a seasonally flooded environment. Cladium and Typha spp. began to grow locally, probably in response to shallower conditions. Corylus, Salix/Populus, and Viburnum spp. were present on the adjacent dry ground.

Zone F3: $10,530-10,270$ to $10,110-9,770$ cal вP. The absence of aquatic material and the decline in other taxa mark the point where the deposits formed beyond the reach of the lake. The presence of a tree stump indicates the insitu growth of Salix/Populus. Emergent vegetation (Cladium, Carex spp. and Typha spp.) was present nearby. Peat formation was interrupted at 10,170-9,890 cal BP by the deposition of a layer of silty sand.

Zone F4a: 10,110-9,770 to 8,620-7,450 cal BP. From the composition of the sediments and the macrofossil assemblage, herbaceous plants (including fen taxa Thalictrum and Eupatorium) had colonised the area as organic sedimentation resumed. Quasi-terrestrial conditions were present locally but it was sufficiently wet to support 

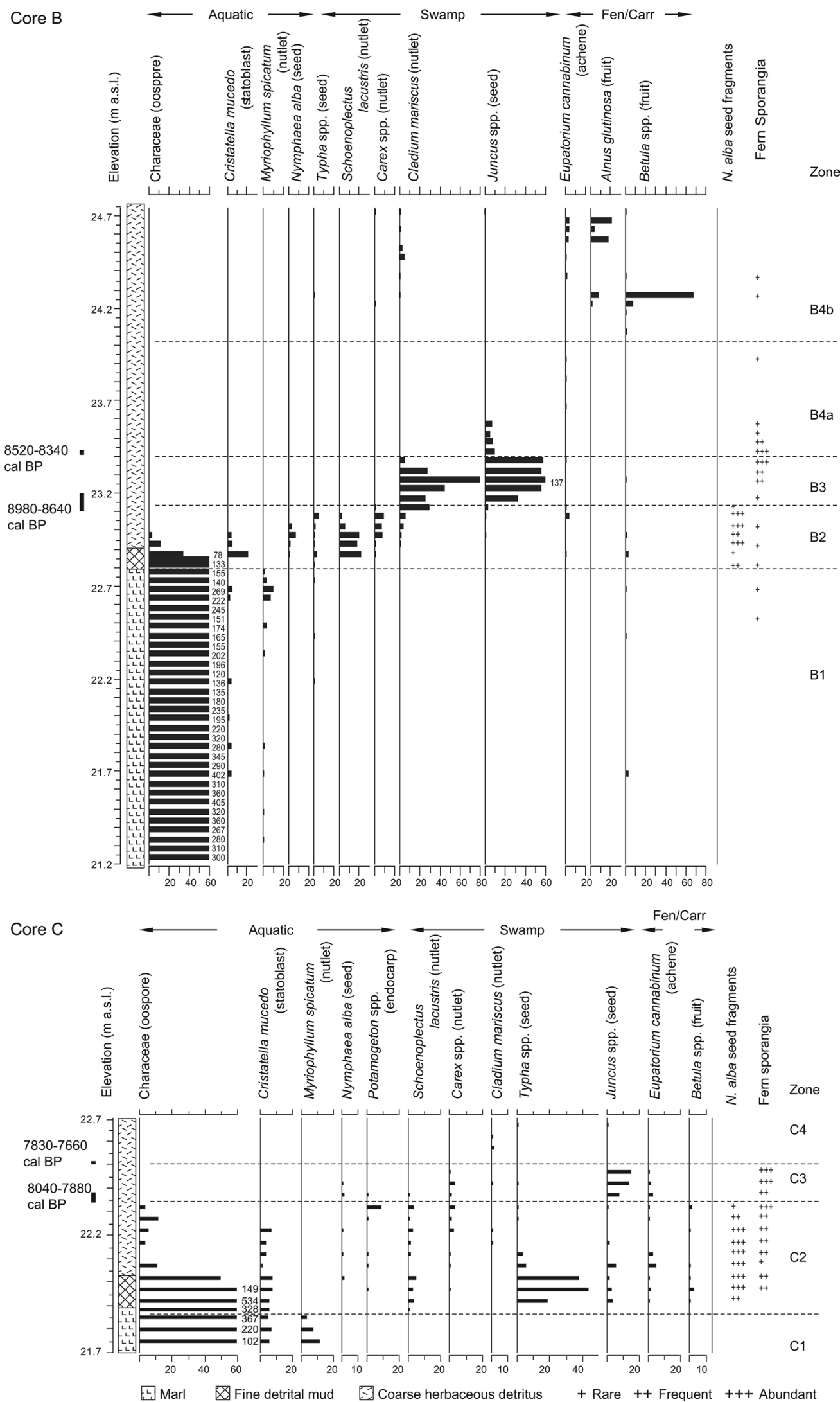
4Fig. 7 a, b Plant macrofossil profiles, core B (top) and C (bottom). Total numbers of macrofossils of each taxon/species are presented, with the exception of $N$. alba seed fragments and fern sporangia which are expressed on a scale of abundance. Profile $B$ has been divided into five zones, and profile $\mathrm{C}$ into four zones based on changes in the plant macrofossil assemblages. The results are displayed stratigraphically, and biological taxa are grouped by broad habitat. Dates are expressed as modelled ages (cal BP) derived from the sequence model (see Table 1)

Menyanthes, at least for part of the time. The first band of humified peat reflects a drop in the local water table, causing the existing deposit to dry out and humify. This started at 9,590-9,480 cal BP with the deposition model indicating a hiatus in peat formation of 70-350 years, before organic sedimentation resumed at 9,440-9,150 cal вр.

Zone F4b: 8,620-7,450 to 7,420-7,090 cal вр. The increasing quantity of macrofossils suggests that the surface of the peat became slightly wetter (improving preservation) though the local vegetation remained unchanged. A subsequent fall in the water-table is marked by the second band of humified peat, which again caused the existing deposits to dry out. This began at 7,560-7,420 cal BP, with a hiatus in peat formation of 10-230 years, before organic sedimentation resumed at 7,430-7,250 cal вр.

F5: 7,420-7,090 to 6,970-6,440 cal вр. Alnus, Urtica, Carex spp. and possibly Corylus colonised the local area. The presence of Alnus cones and wood in the sediment indicating in-situ growth of alder.

Zone A1: $11,690-10,460$ to $11,120-10,360$ cal вр. Open water was present at the sampling point with beds of Characeae present locally.

Zone A2: $11,120-10,360$ to $10,160-9,690$ cal BP. The shift to organic sedimentation reflects a decrease in water depth. Macrofossil records indicate the local presence of aquatic (Potamogeton spp. and Nymphaea) and emergent (S. lacustris, Typha, and Carex) taxa.

Zone A3: 10,160-9,690 to 9,400-9,000 cal вP. The absence of aquatic macrofossils in the basal samples reflects a temporary fall in lake level leaving the deposits above lake-water level. Based on the deposition model this event had a duration of up to 370 years. Cladium and Carex spp. colonised the local area before a rise in lake level (modelled at 10,100-9,500 cal вр) submerged the sampling point, and aquatic and deep-water emergent taxa (Potamogeton spp. and S. lacustris) become re-established. The water-depth gradually shallowed in the upper half of the zone and a Cladium swamp formed at the sampling point.

Zone A4a: start: 9,400-9,000 cal BP; end: uncertain age. The consistent absence of aquatic material indicates that the deposits began to form beyond the extent of the lake. Herbaceous plants, including Hydrocotyle vulgaris, and also ferns were growing locally.
Zone A4b: Undated. Conditions became wetter leading to increased preservation of plant macrofossils, though the deposits remained terrestrial in character. Eupatorium, Urtica and Mentha grew locally.

A5: Undated. Alnus, Betula spp. and Carex spp. colonised the area. As with trench $\mathrm{F}$ the presence of Alnus cones and wood in the deposits indicate in-situ growth of alder.

B1: Undated. Open water was present at the sampling point with Characeae and Myriophyllum spicatum present in the surrounding area.

B2: start: uncertain age; end: $8,980-8,640$ cal вP. The change to organic sediments marks a shift to shallower water. Aquatic and emergent plants (notably Nymphaea, Typha spp., S. lacustris and Carex spp.) grew locally.

B3: 8,980-8,640 to 8,520-8,340 cal вP. The absence of aquatic macrofossils marks the point where the deposits began to form beyond the reach of the lake. Cladium and Juncus spp. were growing locally.

B4a: start: 8,520-8,340 cal вP; end: age uncertain. The deposits remained terrestrialised. Eupatorium, Juncus spp. and ferns were growing locally.

B4b: Undated. Eupatorium, Alnus and Betula spp. grew locally or in the surrounding area. Failure to record Alnus cones or wood suggests that alder was not present at the sampling point.

C1: Undated. Open water was present at the sampling point with Characeae and Myriophyllum growing locally.

C2: start: uncertain age; end: 8,040-7,880 cal вр. The switch to detrital muds indicates a shallowing of the water, emergent and aquatic plants (notably Nymphaea, Potamogeton spp., S. lacustris, and Carex spp.) colonise the local area. Eupatorium seeds reflect the presence of fen nearby.

C3: 8,040-7,880 to 7,830-7,660 cal BP. The decline in the quantity of aquatic macrofossils suggests that the water depth at the sampling point continued to fall. Carex spp., Juncus spp. and Eupatorium grew locally.

C4: start: 7,830-7,660 cal вр; end: age uncertain. The absence of aquatic material marks the point where the deposits formed beyond the extent of the lake. Herbaceous plants, possibly including Cladium and Juncus spp., were present locally.

\section{Trenches $\mathrm{H}$ and I}

Based on the character of the basal organic deposits and the lack of aquatic plant macrofossils, deposition began in a terrestrial fen environment with Eupatorium and Thalictrum growing locally and Betula spp. present in the surrounding area. The deposits subsequently dried out creating a band of dark humified peat. This corresponds stratigraphically with the second band of humified peat recorded in trench $\mathrm{F}$ (see ESM Table 2). The start of this event (in trench F) dates to 7,560-7,420 cal BP. Fen environments returned before 
Table 2 Description of the principal plant macrofossils from trench F, divided into six zones on the basis of changes in the character of the assemblages (see also Fig. 5)

Zone Description

F1 23.5-24.04 m a.s.1.; 11,190-10,730 to 10,690-10,340 cal вр. Taxonomic diversity is high; aquatic, emergent and terrestrial plants are represented. Aquatics consist of Characeae (stonewort), Cristatella mucedo (an aquatic bryozoan), Nymphaea alba (white water lily), and Potamogeton spp. (pondweed). Emergents are best represented by Carex spp. (sedge), including C. rostrata (bottle sedge) and $C$. paniculata (greater tussock sedge), Menyanthes trifoliata (bog bean), and Typha spp. (cattail), with other taxa occurring sporadically (see Fig. S1). Terrestrial plants are dominated by arboreal taxa, notably Betula spp. (birch) (including B. pubescens and B. pendula), and Populus sp. (probably P. tremula, which is represented by its catkin scales)

F2 24.04-24.18 m a.s.1.; 10,690-10,340 to 10,530-10,270 cal BP. Arboreal and aquatic macrofossils fall sharply and diversity declines as Menyanthes disappears along with several of the more sporadically occurring taxa (see Fig. S1). Typha spp. and Cladium increase. Corylus (hazel) is recorded for the first time

F3 24.18-24.47 m a.s.1.; 10,530-10,270 to 10,110-9,770 cal вP. Aquatic taxa no longer recorded and the quantity and range of other taxa declines further. The remains of Betula spp. and Populus sp. occur sporadically, Cladium declines and Carex spp. disappears. Corylus occurs more consistently

F4a 24.47-25.10 m a.s.1.; 10,110-9,770 to 8,620-7,450 cal вP. The quantity and diversity of plant macrofossils remains low and the assemblage composition changes. Fen species, notably Eupatorium cannabinum (hemp agrimony) and Thalictrum flavum (common meadowrue) appear, emergent and arboreal taxa Betula spp., Populus sp., and Corylus are sparse

F4b 25.10-25.34 m a.s.1.; 8,620-7,450 to 7,420-7,090 cal вP. The quantity of plant macrofossils increases and assemblage composition changes. Emergent taxa are no longer present, Eupatorium and Thalictrum increase, and Urtica dioica (common nettle) and Alnus glutinosa (European alder) appear

F5 25.34-23.75 m a.s.l.; 7,420-7,090 to 6,970-6,440 cal вP. Arboreal material (notably Alnus but also Corylus) becomes more common and fen species (Eupatorium and Thalictrum) are absent. Urtica is present towards the top of the zone and Carex spp. occurs sporadically. Above $25.75 \mathrm{~m}$ plant macrofossils were too sparse to analyse

The dates are derived from the deposition model (Fig. 4a; Table 1)

Table 3 Description of the principal plant macrofossils from core A, divided into six zones on the basis of changes in the character of the assemblages (see also Fig. 6)

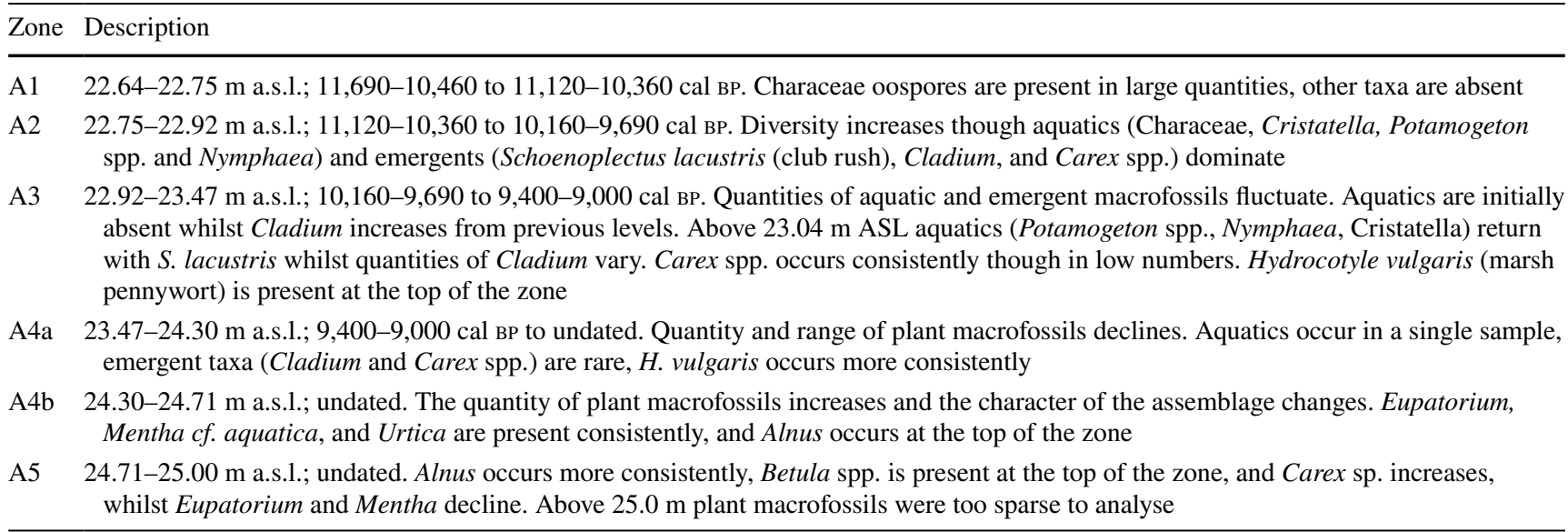

The dates are derived from the deposition model (Fig. 4b; Table 1)

shrubs or trees (including Alnus, and Betula spp.) colonised the area resulting in the layer of wood peat. This transition to Carr was dated in trench F to 7,420-7,090 cal BP, and is likely to be broadly contemporary in trenches $\mathrm{H}$ and $\mathrm{I}$.

\section{Correlating the records}

A radiocarbon chronology for the sequence of environmental change recorded in the plant macrofossil and sedimentary profiles is shown in Fig. 8. In addition, the increase in fen taxa in the upper part of trench $\mathrm{F}$ and core $\mathrm{A}$, which reflects a shift to a slightly wetter depositional environment (zones F4b and A4b, respectively), is assumed to be broadly contemporary.

\section{Evidence for hydrological changes}

Two forms of hydrological change have been documented in this study; the gradual shallowing of the lake due to ongoing sedimentation in the basin, and more rapid fluctuations 
Table 4 Description of the principal plant macrofossils from core B, divided into five zones on the basis of changes in the character of the assemblages (see also Fig. 7a)

Zone Description

B1 21.20-22.80 m a.s.l.; undated. Diversity is low, macrofossils are derived almost entirely from aquatic taxa (Characeae, Cristatella, Myriophyllum spicatum) and the emergent plant Typha sp.

B2 22.80-23.13 m a.s.1.; undated to 8,980-8,640 cal вр. Diversity increases and the assemblage composition changes; Characeae declines and Myriophyllum disappears, whilst Nymphaea occurs for the first time with a range of emergent taxa (Carex spp. S. lacustris, and Cladium) and the fen plant Eupatorium

B3 23.13-23.40 m a.s.1.; 8,980-8,640 to 8,520-8,340 cal BP. Aquatic material disappears and emergent vegetation changes; $C a r e x$ spp. and $S$. lacustris are no longer present, Cladium increases and Juncus spp. (rush) appears

B4a 23.40-24.19 m a.s.1.; 8,520-8,340 cal вP to undated. Diversity remains low, taxa are limited to reduced quantities of Juncus spp. and the sporadic occurrence of Eupatorium and Betula spp. all occurring at very low levels

B4b 4.19-24.75 m a.s.1.; undated. The range and quantity of plant macrofossils increases. Alnus is present consistently, Betula spp. occurs in a single sample, Eupatorium increases, and Carex spp., Cladium, and Typha spp. occur sporadically. Above $24.75 \mathrm{~m}$ macrofossils were too sparse to analyse

The dates are derived from the sequence model (Table 1)

Table 5 Description of the principal plant macrofossils from core C, divided into four zones on the basis of changes in the character of the assemblages (see also Fig. 7b)

\begin{tabular}{ll}
\hline Zone & Description \\
\hline C1 & 21.70-21.86 m a.s.1.; undated. Diversity is low, macrofossils are derived from aquatic taxa (Characeae, Myriophyllum and Cristatella) \\
C2 & 21.86-22.35 m a.s.1.; undated to 8,040-7,880 cal BP. Diversity increases and the composition of the assemblage changes. Characeae \\
& declines and Myriophyllum is no longer recorded, whilst a range of aquatic (Nymphaea and Potamogeton spp.) and emergent/fen taxa \\
& (S. lacustris, Carex spp. Cladium, Typha spp., Juncus spp. and Eupatorium) are present \\
C3 & 22.35-22.50 m a.s.1.; 8,040-7,880 to 7,830-7,660 cal BP. Diversity gradually declines as aquatics and S. lacustris disappear by the top of \\
& the zone. Emergent and fen taxa are unchanged \\
C4 & 22.50-22.70 m a.s.1.; 7,830-7,660 cal BP to undated. Aquatics are absent and the remaining taxa (Cladium and Juncus spp.) are sparse
\end{tabular}

Only the part of the sequence incorporating the decline and disappearance of aquatic material was recorded. The dates are derived from the sequence model (Table 1)

in lake-level/water-table. The chronological relationship between these changes is shown in Figs. 8, 9.

At a general level, the data show the linear development of the lake environments. At each of the sampling points the plant macrofossil assemblage reflects an overall trend from wetter to drier conditions, with the macroremains of aquatic and emergent taxa giving way to macroremains from plants characteristic of wet or boggy ground, and fen or carr environments. With the exception of the earliest fluctuation in lake level recorded in core A (see below), once conditions at each sampling point were such as to be beyond the reach of the lake they remained terrestrialised. Similarly, the chronological relationship between the profiles shows that open water and aquatic environments were succeeded by increasingly shallow and ultimately terrestrial conditions within the basin over time (see Fig. 9).

This broad pattern was interrupted by changes in lake or local water-table levels. The most significant was the fluctuation in lake level recorded in core A. This began at $10,160-9,690 \mathrm{cal}$ вр with a fall in lake level that left the deposits around the sampling point beyond the reach of the lake for up to 370 years. This is contemporary with the deposition of the sand layer in trench F (Figs. 8, 9). Assuming a causal as well as chronological relationship, the sand may have derived from erosion of sediments on the higher ground above the lake edge during this drier phase. However, there is no evidence for a shallowing of the water in cores $\mathrm{B}$ or $\mathrm{C}$ at this time (Fig. 8) indicating that the fall in lake level was not large enough to alter the environment in the deeper parts of the basin.

The subsequent rise in lake level in core $\mathrm{A}$ at 10,100-9,500 cal BP occurs within the same modelled age range as the transition from carr to fen in trench $\mathrm{F}$ (10,110-9,770 cal BP, zone F3-F4a) (Fig. 8). The correlation of these two events suggests that the rising level of the lake caused the deposits at the lake edge to become too wet to support the local growth of trees and thus resulted in fen development. This development is also seen elsewhere within the basin. In trench $F$ the transition from carr to fen coincided with a switch from wood peat to a coarse herbaceous detritus (ESM Table 2a), and a similar stratigraphic horizon was recorded at Seamer Carr (Cloutman 1988b) and other parts of the basin (Paul Lane, personal communication). 

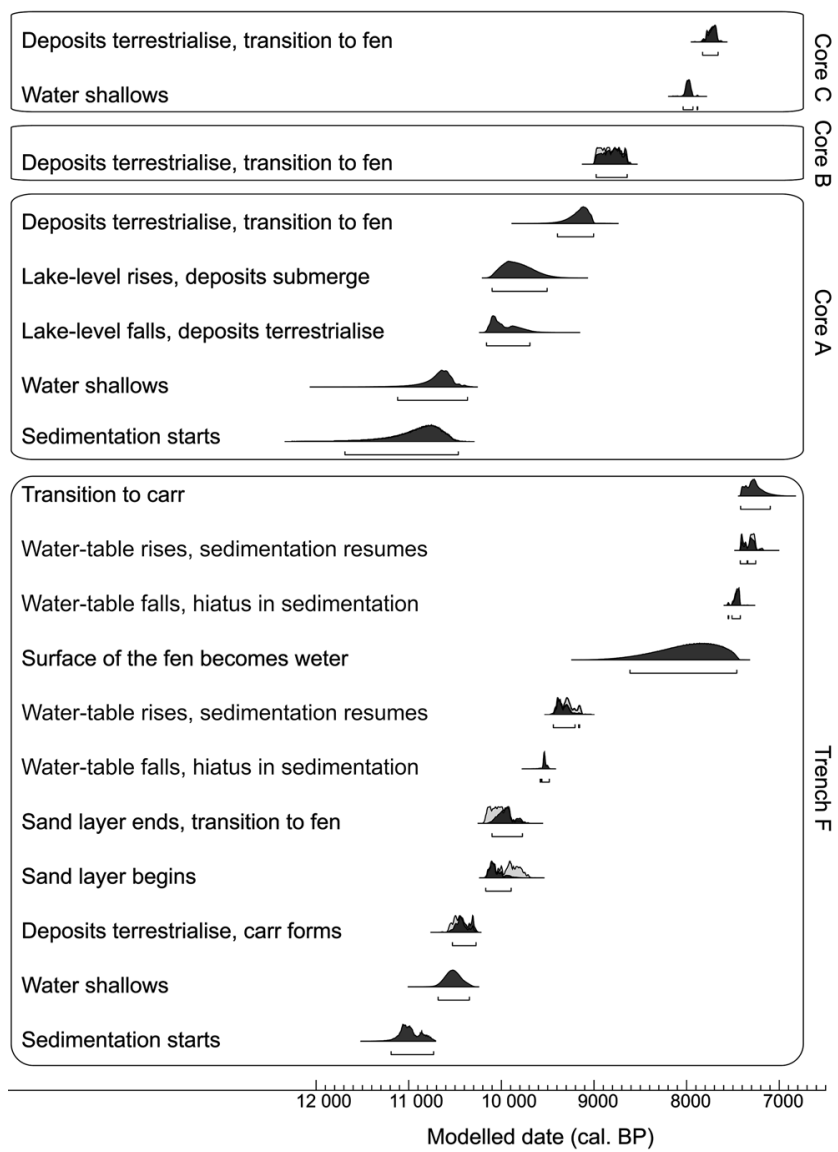

Fig. 8 Probability distributions for the dates of the key plant macrofossil zones and environmental events in all of the profiles. The probability distributions are derived from the deposition models (trench $\mathrm{F}$, core A), and sequence models (cores B and C) presented in Fig. 4a, b and Table 1

The remaining events had a lesser impact on the wider environment. A transition to a slightly wetter environment was inferred from an increase in the quantity of macrofossils recorded in trench F and core A (zones F4b and A4b). The macrofossils show no evidence for a significant change in the local vegetation, and the effects were probably limited to a localised shift to wetter ground conditions that increased macrofossil survival. Two fluctuations in the local water-table were also identified from the sedimentary and chronological record in trench F. In both cases these were represented by a layer of heavily humified peat and a hiatus in organic sedimentation at the interface between the humified layer and the overlying deposit. These represent periods when the surface of the peat dried out causing the extant deposits to humify and peat formation to cease, before a subsequent shift to wetter conditions caused organic sedimentation to resume. There is no evidence for a comparable event in cores $\mathrm{A}-\mathrm{C}$, suggesting that the effects were relatively minor in character and thus limited to the edges of the basin.

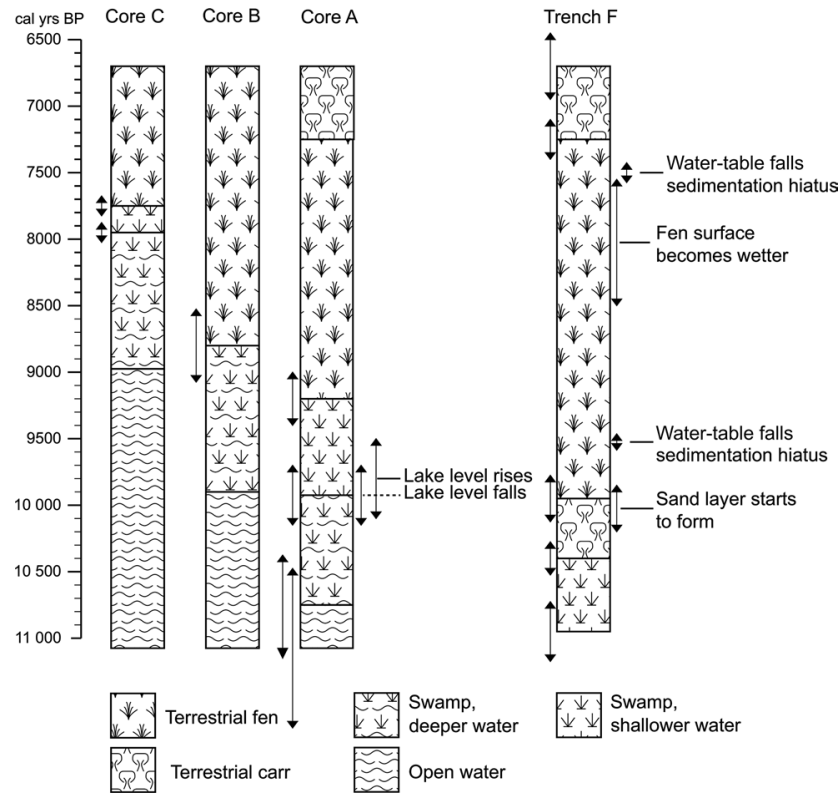

Fig. 9 Schematic representation of the simplified sequence of environmental succession and the key hydrological events in each of the profiles. The vertical lines represent the modelled range of the dates for environmental succession (on the left of each column) and the hydrological changes (on the right of each column). Where no error range is shown the date of environmental change is unknown

Finally, there is no evidence that a rising lake level caused peat-forming environments to expand over previously dry ground (contra Cloutman 1988a, p 14); aquatic material was not recorded in the deposits in trenches $\mathrm{H}$ and I, and the sedimentary sequences and plant macrofossils are indicative of a terrestrial fen. Comparable environments were also recorded in Cloutman's pollen analysis at Seamer Carr (Profile K5), which described a herb and fern-rich fen forming above the former lake shore (Cloutman 1988b, pp 28-30). Rather, the expansion of peat-forming environments over areas of dry ground was probably caused by the accumulation of peat at the lake edge, which would have inhibited drainage from the adjacent mineral sediments above the shore causing them to become waterlogged (a form of edaphic paludification) (Rydin and Jeglum 2006, pp 125-126).

\section{The timing and nature of wetland succession in the Lake Flixton basin}

Organic sediments began to form at the Flixton SHF lake edge in the centuries around 11,000 cal BP with marl accumulating in the deeper water at the site of core A (and potentially B and C). Species diversity was high within the lake. Phragmites was growing at trench F, and other emergent species, notably Menyanthes, Typha spp. and Carex (including $C$. paniculata and $C$. rostrata), were growing in the surrounding area. A similar range of taxa was recorded from 
contemporary sediments at Star Carr (Dark 1998a; Taylor and Alison 2018) and No Name Hill (Taylor 2011), indicating the rich and diverse nature of the marginal vegetation. Aquatic plants Nymphaea, Myriophyllum and Potamogeton spp. were also present, probably in deeper water further from the shore, along with beds of the aquatic algae Characeae. Trees (Populus tremula, Betula pubescens and B. pendula, and Salix spp.) were growing at the water's edge. Beyond the lake, pollen analysis has recorded a landscape of grassland and scrub with Juniperus, Salix and Betula that was replaced by Betula woodland from ca 11,100 cal вР (Fig. 4 in Blockley et al. 2018).

The lake-edge environments changed rapidly over the following centuries. Emergent and aquatic species had colonised core A by ca $10,750 \mathrm{cal}$ в. At trench F the deposits were only seasonally submerged by ca $10,500 \mathrm{cal} \mathrm{BP}$, encouraging the local growth of Cladium, with the deposits forming beyond the reach of the lake by ca 10,400 cal вр. This allowed trees (Salix/Populus) to spread onto the peat. The same sequence has been recorded at Star Carr where Cladium increases following the shift to a shallower environment (Taylor and Alison 2018, p 130), before the lake edge deposits became terrestrialised and resulted in fen and carr forming by 10,450-10,165 cal вP (Supp Info 20-21 in Blockley et al. 2018,). Assuming a similar rate of sedimentation in other parts of the basin the embayments at Seamer Carr, Lingholme, and Cayton (Fig. 2) were probably also becoming terrestrialised at this time (see Taylor et al. 2018b, p 49). However, within the main body of the lake the extent of these environments was still limited to the area close to the shore with vegetation characteristic of deeper water persisting at core $\mathrm{A}$, and open water also persisting in the vicinity of cores B and C. On the shore, Viburnum spp. and Corylus were growing at Flixton SHF from ca 10,500 cal $\mathrm{BP}$, the presence of the latter in the wider landscape also being reflected in the low but consistent presence of its pollen (e.g. Cloutman 1988b; Dark 1988a, b; Day 1996). The dating undertaken by Cloutman (1988a) shows that peatforming environments were already established on areas of dry ground at Seamer Carr Site K (Fig. 2).

The period from ca 10,000 to ca $9,000 \mathrm{cal}$ BP was characterised by changes to both the wetland and terrestrial environments. At ca 9,900 cal вР the lake level fell causing the area around core A to become terrestrialised. Emergent and aquatic plants probably expanded further into the basin creating an extensive area of wetland vegetation (though not as far as core B where open water conditions persisted). A subsequent rise in the level of the lake, up to 370 years later, resulted in flooding in the area around core A and reversion to an aquatic swamp. Deposits at the lake edge were now too wet to support growth of trees. Fen communities consisting of herbaceous plants (including Thalictrum and Eupatorium) replaced carr at trench $\mathrm{F}$ and other locations around the former shore. At ca 9,500 cal вP the local watertable fell causing the deposits around the edge of the lake to dry out and humify, before wetter conditions returned up to 350 years later. Peat was starting to encroach over previously dry ground at VP Site E and parts of the Star Carr peninsula (see Fig. 2) by this time (see Cloutman 1988a), and was probably also developing at Flixton SHF. On drier ground Corylus became the principal component of the woodland, an event dated at Star Carr to 10,250-9,730 cal вр (8,940 \pm 90 вр. OxA-4377) (Dark 1988a, p 133), and Ulmus, and to a lesser extent Quercus, began to expand into the area, shading out much of the understory vegetation (Day 1996, pp 16-17; Dark 1998b, p 170).

Despite these hydrological changes the lake environments continued to develop in the manner of a classic hydrosere. By ca 9,200 cal вP the deposits at core A were forming beyond the reach of the lake water. Emergent species were probably already present around core B, and by ca $8,800 \mathrm{cal}$ BP had been replaced by Cladium fen, creating a zone of terrestrialised wetland that extended lakewards at least $150 \mathrm{~m}$ from the former shore. Aquatic and deep water emergent communities may also have been present around core $\mathrm{C}$ from this time, and were colonising the deeper parts of the basin by $8,600-8,300$ cal вр (94.6\% probability) $(7,640 \pm 83$ вр. OxA-4042) (Day 1996, p 17; Dark 1998b, p 170). On dry ground, the pollen evidence indicates that Quercus became more common, and, along with Ulmus and Corylus, formed a significant component of the woodland whilst Alnus spread to the area (Day 1996, p 17; Dark 1998b, p 170), and probably colonised drier areas within the wetland.

From ca 8,000 cal BP the hydrosere entered its final phase as the water around core $\mathrm{C}$ became increasingly shallow and then terrestrialised at ca 7,750 cal BP. Standing water may have persisted in some places, and may have resulted in small pools within a wider mosaic of swamp, fen and carr. The deposits around trench $\mathrm{F}$ dried out for a second time at ca 7,500 cal вP, though the effects appear to have been limited to the edge of the basin. Shortly after organic sedimentation resumed Alnus colonised the site (ca 7,250 cal вP) and probably the area around core A. Fen environments persisted around cores $\mathrm{B}$ and $\mathrm{C}$, though the occurrence of Alnus and Betula macrofossils suggests at least some tree cover locally.

\section{Implications for Mesolithic activity}

The first Mesolithic groups arrived in the area at ca 11,300 cal вP (Milner et al. 2018), with evidence for activity at multiple locations around the lake within the following centuries (Conneller et al. 2016; Taylor 2018). This phase of settlement is strongly associated with the lake environments and the exploitation of wetland resources. Activity areas were located on or close to the shore and have yielded evidence for fishing, fowling, hunting of aquatic mammals, 
and the collection and processing of wetland plants (Clark 1954; Taylor 2011, 2012, 2018; Taylor et al. 2018a; Robson et al. 2018).

Initial changes to the lake environments had little effect on this pattern of activity with sites continuing to be occupied as the lake edge became shallower and ultimately terrestrialised, and emergent vegetation extended further from the shore (see Taylor 2011, 2012, 2018; Milner et al. 2018). Indeed, the early stages of wetland succession were probably beneficial to early Mesolithic groups as the expansion of swamp and carr within the shallower embayments created a mosaic of habitats suitable for fish, waterfowl, and some of the larger mammals.

This pattern of settlement began to change from the latter stages of the early Mesolithic as sites on low-lying ground close to the shore were abandoned. The recent excavations at Star Carr, which focused on the area between $24 \mathrm{~m}$ and $25 \mathrm{~m}$ a.s.l., show occupation ending ca 10,500 cal вP (Milner et al. 2018; Blockley et al. 2018), whilst activity at Seamer Carr site C (which lay at a similar elevation) had ceased by ca 10,000 cal вP (Conneller et al. 2016) (site locations in Fig. 2). In addition, there is no evidence for late Mesolithic settlement on early Mesolithic occupation sites at VP-D, VP-E, Seamer Carr site D, and Flixton Island (Table 1 in Conneller and Schadla-Hall 2003), all of which lie on or below $25 \mathrm{~m}$ a.s.l. (Fig. 2), and only minimal activity at Seamer Carr site K, which lies at a similar elevation. In contrast sites on higher ground, such as Flixton SHF, Flixton School Field, Barry's Island and No Name Hill continued to be occupied into the late Mesolithic along with new sites (such as Rabbit Hill) on similarly elevated positions (Fig. 2).

The changes described above were probably a response to the expansion of peat-forming environments over areas of dry ground, a process that would have rendered low-lying areas adjacent to the shore unsuitable for settlement. In turn, the shift to higher ground changed the environmental context of the later sites, which now lay either at the junction between fen and the terrestrial woodland or, in the case of the former islands or peninsulas, on small wooded hills surrounded by wetlands. Indeed, from ca $9,000 \mathrm{cal}$ BP it is more appropriate to describe these sites as occupying a wetland edge, rather than a lake-edge environment, as areas of open water receded into the basin.

As well as the shift in settlement, patterns of economic activity would have changed as both terrestrial woodland and wetland succession altered the availability of plant resources and the habitats of prey animals. However, these changes need not have been as unfavourable to the human population as has been suggested (contra Mellars 1998, p 230). Though the lake was infilling with fen, this would have been bordered by an extensive woodland-edge environment made up of younger saplings and shade intolerant species such as Salix and Populus tremula. This would have resulted in habitats suitable for browsers such as red and roe deer. Given that the development of closed canopy woodland is generally thought to have reduced the size of large mammal populations (e.g. Mellars 1976), the persistence of large areas of fen and woodland-edge resulted in the Lake Flixton landscape remaining an important area for both settlement and hunting throughout the much of the Mesolithic.

\section{Conclusions}

Plant macrofossil analysis and radiocarbon dating have established the timing and nature of wetland succession in Lake Flixton. Fluctuations in lake-level had a significant effect on the local environment, although there is no evidence for a sustained rise in lake-level. The early development of the wetlands had little effect upon the pattern of human activity and may even have been beneficial for the early Mesolithic populations by creating a diverse range of highly productive environments. From the later part of the early Mesolithic (ca 10,500 cal BP), environmental change had affected patterns of settlement and economic activity, though the area remained inhabited. This project demonstrates the importance of plant macrofossil studies for tracking changes in lakes and wetlands associated with human activity and settlement, and the need for well-dated palaeoenvironmental records at a local scale when interpreting the effects of early Holocene environmental change on patterns of human activity.

Acknowledgements The plant macrofossil analysis for trenches F, H and I, and core A were carried out as part of the author's AHRCfunded doctoral research (AHRC Doctoral Award 2007/135399). The radiocarbon chronologies for those profiles were supported by a Grant from NERC/ORAU (NF/2009/1/20), and the fieldwork at Flixton was supported by funding from by the Vale of Pickering Research Trust. My thanks to Amy Gray Jones who co-directed the excavations, Nick Overton and Pete Ryan for assistance with the coring, and Jeff Blackford, Mel Giles and Jamie Woodward for advice and support throughout my doctoral thesis. I also thank the two anonymous referees and Michael O'Connell for their comments on the earlier drafts of this paper. All errors remain my own.

Open Access This article is distributed under the terms of the Creative Commons Attribution 4.0 International License (http://creativeco mmons.org/licenses/by/4.0/), which permits unrestricted use, distribution, and reproduction in any medium, provided you give appropriate credit to the original author(s) and the source, provide a link to the Creative Commons license, and indicate if changes were made.

\section{References}

Birks HH (1973) Modern macrofossil assemblages in lake sediments in Minnesota. In: Birks HJB, West RG (eds) Quaternary plant ecology. Blackwell, Oxford, pp 173-189 
Blockley S, Candy I, Matthews I et al (2018) The resilience of postglacial hunter-gatherers to abrupt climate change. Nat Ecol Evol 2:810-818

Bronk Ramsey C (2009a) Bayesian analysis of radiocarbon dates. Radiocarbon 51:337-360

Bronk Ramsey C (2009b) Dealing with outliers and offsets in radiocarbon dating. Radiocarbon 5:1,023-1,045

Bronk Ramsey C (2017) Methods for summarizing radiocarbon datasets. Radiocarbon 59:1,809-1,833

Cappers RTJ, Bekker RM, Jans JEA (2006) Digitale zadenatlas van Nederland (Digital seed atlas of the Netherlands). Groningen Archaeological Studies 4. Barkhuis, Eelde

Clark JGD (1954) Excavations at Star Carr. Cambridge University Press, Cambridge

Cloutman E (1988a) Palaeoenvironments in the Vale of Pickering, part 1: stratigraphy and palaeogeography of Seamer Carr, Star Carr and Flixton Carr. Proc Prehist Soc 54:52-69

Cloutman E (1988b) Palaeoenvironments in the Vale of Pickering, part 2: environmental history at Seamer Carr. Proc Prehist Soc $54: 21-36$

Conneller C, Schadla-Hall RT (2003) Beyond Star Carr: the Vale of Pickering in the tenth millennium BP. Proc Prehist Soc 69:85-105

Conneller C, Milner N, Taylor B, Taylor M (2012) Substantial settlement in the European early Mesolithic: new research at Star Carr. Antiquity 86:1,004-1,020

Conneller C, Bayliss A, Milner N, Taylor B (2016) The resettlement of the British landscape: towards a chronology of Early Mesolithic lithic assemblage types. Internet Archaeol. https://doi. org/10.11141/ia.42.12

Cummins G (2003) Impacts of hunter-gatherers on the vegetation history of the Eastern Vale of Pickering, Yorkshire. PhD thesis, Durham University

Dark P (1998a) Lake edge sequences: results. In: Mellars P, Dark P (eds) Star Carr in context: new archaeological and palaeoecological investigations at the early Mesolithic site of Star Carr, North Yorkshire. McDonald Institute for Archaeological Research, Cambridge, pp 125-146

Dark P (1998b) The lake centre sequence: results. In: Mellars P, Dark P (eds) Star Carr in context: new archaeological and palaeoecological investigations at the early Mesolithic site of Star Carr, North Yorkshire. McDonald Institute for Archaeological Research, Cambridge, pp 163-178

Day P (1996) Devensian late-glacial and early Flandrian environmental history of the Vale of Pickering, Yorkshire, England. J Quat Sci 11:9-24

Grosse-Brauckmann G (1972) Über pflanzliche Makrofossilien mitteleuropäischer Torfe. I: Gewebereste krautiger Pflanzen und ihre Merkmale. Telma 2:19-55

Grosse-Brauckmann G (1974) Über pflanzliche Makrofossilien mitteleuropäischer Torfe. II: Weitere Reste (Früchte und Samen, Moose u.a.) und ihre Bestimmungsmöglichkeiten. Telma 4:51-117

Grosse-Brauckmann G (1992) Über pflanzliche Makrofossilien mitteleuropäischer Torfe. III: Früchte, Samen und einige Gewebe (Fotos von fossilen Pflanzenresten). Telma 22:53-102

Haslam SM (1972) Biological flora of the British Isles, Phragmites communis. Trin J Ecol 60:585-610

Juggins S (2010) C2 1.66 Software for ecological and palaeoecological data analysis and visualization. https://www.staff.ncl.ac.uk/steph en.juggins/software/C2Home.htm. Accessed 12 Feb 2016

Koff T, Vandel E (2008) Spatial distribution of macrofossil assemblages in surface sediments of two small lakes in Estonia. Estonian J Ecol 57:5-20

Mellars P (1976) Fire ecology, animal populations and man: a study of some ecological relationships in prehistory. Proc Prehist Soc $42: 15-45$
Mellars P (1998) Postscript: major issues in the interpretation of Star Carr. In: Mellars P, Dark P (eds) Star Carr in context: new archaeological and palaeoecological investigations at the early Mesolithic site of Star Carr, North Yorkshire. McDonald Institute for Archaeological Research, Cambridge, pp 215-242

Mellars P, Dark P (1998) Star Carr in context: new archaeological and palaeoecological investigations at the early Mesolithic site of Star Carr, North Yorkshire. McDonald Institute for Archaeological Research, Cambridge

Milner N, Taylor B, Conneller C, Bayliss A (2018) Interpretative narrative of the history of occupation. In: Milner $\mathrm{N}$, Conneller $\mathrm{C}$, Taylor B (eds) Star Carr, vol 1: a persistent place in a changing world. White Rose University Press, York, pp 225-244

Reimer PJ, Bard E, Bayliss A et al (2013) IntCal13 and Marine13 radiocarbon age calibration curves $0-50,000$ years cal BP. Radiocarbon 55:1,869-1,887

Robson HK, Little A, Jones AKG et al (2018) Scales of analysis: evidence of fish and fish processing at Star Carr. J Archaeol Sci Rep 17:895-903

Rydin H, Jeglum J (2006) The biology of peatlands. Oxford University Press, Oxford

Schweingruber FH (1990) Microscopic wood anatomy. Structural variability of stems and twigs in recent and subfossil woods from Central Europe, 3rd edn. Swiss Federal Institute for Forest, Snow and Landscape Research, Birmensdorf

Stace C (2010) New flora of the British Isles, 3rd edn. Cambridge University Press, Cambridge

Taylor B (2011) Early Mesolithic activity in the wetlands of the Lake Flixton Basin. J Wetl Archaeol 11:63-84

Taylor B (2012) The occupation of wetland landscapes during the British Mesolithic: case studies from the Vale of Pickering. Ph.D. thesis, University of Manchester

Taylor B (2018) Subsistence, environment and Mesolithic landscape archaeology. Camb Archaeol J 28:493-510

Taylor B, Alison E (2018) Palaeoenvironmental investigations. In: Milner N, Conneller C, Taylor B (eds) Star Carr, vol 2: studies in technology, subsistence and environment. White Rose University Press, York, pp 123-149

Taylor B, Gray Jones A (2009) Definitely a pit, possibly a house? Recent excavations at Flixton School House Farm in the Vale of Pickering. Mesolith Misc 20:21-26

Taylor B, Conneller C, Milner N, Elliott B, Little A, Knight B, Bamforth M (2018a) Human lifeways. In: Milner N, Conneller C, Taylor B (eds) Star Carr, vol 1: a persistent place in a changing world. White Rose University Press, York, pp 245-272

Taylor B, Blockley S, Candy I et al (2018b) Climate, environment and Lake Flixton. In: Milner N, Conneller C, Taylor B (eds) Star Carr, vol 1: a persistent place in a changing world. White Rose University Press, York, pp 41-54

Walker D, Godwin H (1954) Lake stratigraphy, pollen-analysis and vegetational history. In: Clark JGD (ed) Excavations at Star Carr: an early Mesolithic site at Seamer near Scarborough, Yorkshire. Cambridge University Press, Cambridge, pp 25-69

Zhao Y, Sayer CD, Birks HH, Hughes M, Peglar SM (2006) Spatial representation of aquatic vegetation by macrofossils and pollen in a small and shallow lake. J Palaeolimnol 35:335-350

Publisher's Note Springer Nature remains neutral with regard to jurisdictional claims in published maps and institutional affiliations. 